\title{
Cyclic Siloxane Biosurfactant Producing Bacillus Sp. BS14 Biocontrol Charcoal Rot Pathogen Macrophomina Phaseolina and Induce Growth Promotion in Vigna Mungo L.
}

\section{Sumit Kumar}

Gurukula Kangri University: Gurukula Kangri vishwavidyalaya

Ramesh Chandra Dubey

Gurukula Kangri University: Gurukula Kangri vishwavidyalaya

Dinesh Kumar Maheshwari

Gurukula Kangri University: Gurukula Kangri vishwavidyalaya

Nitin Baliyan

Gurukula Kangri University: Gurukula Kangri vishwavidyalaya

Shrivardhan Dheeman ( $\nabla$ svdheeman@gmail.com )

Sardar Bhagwan Singh University https://orcid.org/0000-0001-6879-8635

\section{Research Article}

Keywords: Bacillus, Biosurfactant production, Plant growth-promoting rhizobacteria, Biocontrol

Posted Date: April 8th, 2021

DOl: https://doi.org/10.21203/rs.3.rs-389451/v1

License: (c) (1) This work is licensed under a Creative Commons Attribution 4.0 International License. Read Full License

Version of Record: A version of this preprint was published at Archives of Microbiology on July 22nd, 2021. See the published version at https://doi.org/10.1007/s00203-021-02492-3. 
1 Cyclic siloxane biosurfactant producing Bacillus sp. BS14 biocontrol charcoal rot pathogen

2 Macrophomina phaseolina and induce growth promotion in Vigna mungo $\mathrm{L}$.

3 Sumit Kumar ${ }^{1}$, Ramesh C. Dubey ${ }^{1}$, Dinesh K. Maheshwari ${ }^{1}$, Nitin Baliyan ${ }^{1}$, Shrivardhan Dheeman ${ }^{1,2}$

$4 \quad{ }^{1}$ Department of Botany and Microbiology, Gurukula Kangri Deemed to be University, Haridwar -249 404

5 Uttarakhand, India

$6 \quad{ }^{2}$ Department of Microbiology, School of Life Science, Sardar Bhagwan Singh University, Dehradun - 248161

$7 \quad$ Uttarakhand, India

8

9 Corresponding Author(s)

10 Prof. R. C. Dubey, E-mail: profrcdubey@gmail.com

11 Dr. Shrivardhan Dheeman, E-mail: svdheeman@gmail.com

Author Contributions

SK designed and conceived the experiment under mentorship of RCD. SD assisted during the experiments and NB helped during manuscript writing. RCD and DKM read the manuscript for scientific correction and approved for communication.

\section{Acknowledgment}

SK is thankful to the Head, Department of Botany \& Microbiology for providing laboratory facilities.

\section{Ethical statement}

This research did not involve any animal and/ or human participants.

\section{Conflict of Interest}

The authors declare that they have no conflict of interests.

\section{Funding Disclaimer}

This research is not supported by any funding. 


\section{Abstract}

Rhizobacteria are important component of soil-plant interfaces and help in the management of plant diseases by various means. Precisely, the role of biosurfactant is underscored in biocontrol. The current study showed the exploration of biosurfactant-producing bacteria and its effect in indirect reduction of disease severity in pulse crops. In this study, BS14 was screened as plant growth promoting, biosurfactant producing and biocontrol agent against Macrophomina phaseolina. The biosurfactant purified for biocontrol assays and shown inhibition of fungal hyphal growth in dual culture method and cellular-level deformities in mycelia of M. phaseolina, as observed under scanning electron microscopic (SEM). The biosurfactant of Bacillus BS14 was identified as cyclic siloxane in GC-MS-spectroscopy and FTIR-spectroscopy analysis. In pot-trial studies Bacillus sp. BS14 proved their efficiency for the growth-promotion of Vigna mungo and significant reduction in disease severity index.

38 Using biosurfactants is a biological alternative to the control of plant diseases.

39 Keywords: Bacillus, Biosurfactant production, Plant growth-promoting rhizobacteria, Biocontrol 
42

43

44

45

46

47

48

49

50

51

52

53

54

55

56

57

58

59

60

61

62

63

64

65

The by-products (enzymes, antibiotics, vitamins, bioorganic acids) secreted by microorganisms showed beneficial effects towards environment, industries, medicine, and agriculture (Lynch et al. 1976; Singh et al. 2017). The products of microbial origin have various utilization in agriculture under the aim to increase crop productivity and soil-fertility management in an eco-safe way (Maheshwari et al. 2013; Maheshwari 2015). Such metabolites like biosurfactants or bio-emulsifiers are precious compounds as they can condition the soil and restrict the growth of phytopathogens for disease control. (Sachdev and Cameotra 2013). The rhizobacteria enhance plant growth via several mechanisms such as phytohormone production, secretion of iron-chelating siderophores, solubilization of insoluble phosphatic salts in the soil, induction of plant-immunity, stress management by ACC-deaminase activity, and controlling fungal phytopathogens in the rhizosphere (Bee et al. 2019).

Besides, some studies talk about certain biosurfactants for the enhancement of rhizobacterial colonization and other means of biocontrol (Sarwar et al. 2018a) Bacillus spp. often considered as an elite production source of a comprehensive array of biologically active molecules, such as lipopeptides (LPs) which protect plant from fungal diseases (Agarwal et al. 2017). Earlier, Romano et al. (2013) have purified cyclic lipopeptides from Bacillus amyloliquefaciens strain BO5A and checked its antifungal activity against pathogenic fungi Fusarium oxysporum, Aspergillus niger, Botrytis cinerea, and Penicillium italicum. Moreover, the production of a wide range of antimicrobial substances by many bacteria, such as lipopeptides (biosurfactants) is consecutively produced by bacilli that demonstrate antibacterial and antifungal activity against a wide array of pathogenic bacteria and fungi (Kumar and Johri 2012). A biosurfactant producing Bacillus sonorensis MBCU2 was isolated from vermin compost-amended soil showed potential antagonistic activity against $M$. phaseolina in vitro assays (Pandya and Saraf 2015). A qualitative analysis of biosurfactant from Bacillus was carried out along with studies on antifungal properties by Sarwar et al. (2018b). A quantum of reports appeared establishing Bacillus as a producer of LPs biosurfactant (Sarwar et al. 2018a, b; Hafeez et al. 2019). On the other hand, Al-Ali et al. (2018) demonstrated that the production of exopolysaccharide (EPS) has the main importance of biofilm formation and rhizosphere colonization. Naturally, exopolysaccharide (EPS) produce silicones, when reacting with siloxanes to form organic siloxane; which is also produced by Bacillus mucilaginosus var. siliceous as reported by Avakyan et al. (1986). Cyclic siloxanes are very useful to produce silicone surfactants and foam polyurethane for foam applications (Hil et al. 2002). Recently, a US patent (US20190059385A1) has appeared to increase agronomic yield using the functional approach of siloxanes biosurfactants in agriculture (Hänsel et al. 2019). 

has been in cultivation from the distant past or is one of the utmost prized pulses of India. It is broadly used in Indian food. The plant cultivates $35-110 \mathrm{~cm}$ and $4-6 \mathrm{~cm}$ seedpods. $V$. mungo is more nutritious as it holds high value of protein, $\mathrm{C}, \mathrm{K}, \mathrm{Fe}$, thiamine, riboflavin, niacin, folate and essential amino acids. In medieval eyes, this cereal has been used in making crucibles resistant.

Macrophomina phaseolina (Tassi) Goid is the most exterminator phytopathogens of Vigna mungo along with almost 500 plant species throughout the world causing charcoal-rot and reducing the yield (Arora et al. 2001; Gupta et al. 2002; Khalil et al. 2016; Shahid and Khan 2019; Pandey et al. 2020) Vigna mungo (L.) Hepper is a vital annual pulse crop and valued for its high digestibility and liberty from any harmful effect. Therefore, the use of biosurfactant producing and plant growth-promoting Bacillus for an increase in crop production and inhibition of pathogens is the best alternative because they are spore-formers, long survival in hares conditions, and produce toxic metabolites inhibitory to phytopathogens (Bais et al. 2004). The present study was carried out to identify the beneficial roles of biosurfactant-producing and plant growth-promoting Bacillus from the rhizospheric soil (Udic Haplustepts) of V. mungo and shown their application as plant growth-promoting rhizobacteria (PGPR) for plant growth promotion and biocontrol of M. phaseolina in the rhizosphere.

\section{Materials and Methods}

\subsection{Isolation of putative microorganisms}

Healthy plants of V. mungo were collected from different farmer's fields in district Saharanpur of state Uttar Pradesh, India $\left(29.919^{\circ} \mathrm{N} 77.304^{\circ} \mathrm{E}\right)$, carried to the laboratory in sterile polythene bags. Isolates were identified as spore-forming after heat treatment and serial dilution technique as described by Agarwal et al. (2017). Microcolonies were purified by streaking and designated with laboratory code for prior identification of isolates by cultural and biochemical tests, such as Gram-staining, spore staining, motility test, oxidase test, indole test, catalase test, citrate test, coagulase test, methyl red, and Vogues Proskauer test.

\subsection{Screening of biosurfactant production}

All the bacterial isolates were initially screened for biosurfactant production via various screening procedure such as mineral salt cetyl-trimethyl-ammonium-bromide (CTAB) - methylene blue agar plate assay (Siegmund and Wagner 1991), hemolytic activity (Youssef et al. 2004), bacterial adherence to hydrocarbons (BATH) assay (Rosenberg et al. 1980), drop collapse assay (Jain et al. 1991), oil spreading assay (Rodrigues et al. 2006), 
Emulsification stability (E24) test (Das et al. 2008), and measurement of surface tension of cell-free culture broth according to Du Nouy's ring method (Lunkenheimer and Wantke 1981), with the modification as previously carried out in our study (Kumar et al. 2016)

\subsection{Isolation of plant growth-promoting bacteria}

The determination of IAA production by bacterial isolates was grown on LB broth and incubated at $28{ }^{\circ} \mathrm{C}$ for 24 $\mathrm{h}$ at $120 \mathrm{rpm}$. Exponentially grown culture $\left(10^{8} \mathrm{cfu} \mathrm{ml}^{-1}\right)$ was centrifuged at $10,000 \mathrm{rpm}$ for 20 minutes at $4{ }^{\circ} \mathrm{C}$ to collect the supernatant; $2 \mu \mathrm{l}$ of ortho-phosphoric acid was added to $2 \mathrm{ml}$ of supernatant with the subsequent addition of Salkowski's reagent. The plausibility of pink color confirmed IAA production. Further, HCN (cyanogen) production was determined following the modified method of Bakker and Schippers (1987). Siderophore production was evaluated on Chrome-azurol S (CAS) medium by spot inoculating bacterial culture and incubated at $28 \pm 1{ }^{\circ} \mathrm{C}$ for $48-72 \mathrm{~h}$ (Schwyn and Neilands 1987). The formation of orange to yellow halo around the bacterial colonies confirmed siderophore production. Phosphate solubilization ability of all isolates was detected by spotting them separately on Pikovskaya's agar plates (De Freitas et al. 1997). These plates were then incubated at $28 \pm 1^{\circ} \mathrm{C}$ for 3 days and observed for the appearance of the clearing zone around the colonies. The qualitative assay for chitinase production was performed following the method of Dunne et al. (1997). Isolates were separately inoculated by spotting on the plates containing chitin minimal medium (CMM) as the sole source of carbon and incubated at $30 \pm 2{ }^{\circ} \mathrm{C}$ for 7 days. These plates were examined for the development of clear zones around the bacterial colonies.

\subsubsection{Biofilm assay}

Sterile Muller Hinton broth (MHB) $(5 \mathrm{ml})$ was poured in the pre-sterile test tubes inoculated separately with the test organisms along with proper control and incubated at $37{ }^{\circ} \mathrm{C}$ for $24 \mathrm{~h}$. The broth was discarded, washed with 0.5 M phosphate buffer saline (PBS) and the internal surface of the tube was stained with $1 \%$ crystal violet solution to confirm biofilm formation (O’Toole, 2011).

\subsection{Biochemical and physiological characterization}

The biochemical characterization of isolates was carried out followed by Bergey's Manual of Determinative Bacteriology (Holt et al. 1994). Different phenotypic characters of these isolates were compared with the standard strains, such as Bacillus sp. (MTCC 297) and Bacillus subtilis (MTCC 441) which were procured from the Institute 

of Bacillus.

\subsection{Molecular characterization}

The 16S rRNA gene sequencing of the isolate BS14 was performed after isolation of bacterial DNA following Sambrook and Russell (2001) and PCR amplified by using universal primer 27F 5'AGAGTTTGATCMTGGCTCAG3' and 1492R 3'CGGTTACCTTGTTACGACTT5' gene sequence. The DNA sequences were assembled and subjected to analysis at NCBI. The sequences were deposited to GenBank to get the accession number of the isolate. The phylogeny tree was constructed by employing the neighbor-joining method using MEGA 6.0.

\subsection{Production and purification of biosurfactant}

135

The biosurfactant-producing potential isolate BS14 was transferred to $5 \mathrm{ml}$ nutrient-rich (NR) broth containing $1 \%$ yeast extract $1.5 \%$ nutrient broth and $1 \%$ ammonium sulfate and incubated at $37{ }^{\circ} \mathrm{C}$ for $12 \mathrm{~h}$ and $120 \mathrm{rpm}$ as seed culture to get the optical density of 0.5 at $600 \mathrm{~nm}$. Further, $5 \mathrm{ml}$ suspension of BS14 was transferred to a $1000 \mathrm{ml}$ Erlenmeyer flask containing $500 \mathrm{ml}$ of LB medium and incubated on a rotary shaker incubator (150 rpm) at 37 ${ }^{\circ} \mathrm{C}$. The bacterial cells were removed by centrifugation at $10,000 \mathrm{rpm}$ at $4{ }^{\circ} \mathrm{C}$ for $20 \mathrm{~min}$ and the supernatant was acidified with $6 \mathrm{~N}$ hydrochloric acid to get the $\mathrm{pH} 2.0$. The precipitate containing biosurfactant allowed to settle at $4{ }^{\circ} \mathrm{C}$ overnight and collected by centrifugation at 15,000 rpm for $20 \mathrm{~min}$. The precipitate was dissolved in distilled water after centrifugation to get $\mathrm{pH} 7.0$ using $1 \mathrm{~N} \mathrm{NaOH}$. Again, it was centrifuged at 10,000 rpm for $10 \mathrm{~min}$ following Sanchez et al. (2007).

\subsection{In vitro Antagonistic activity}

The fungal pathogen M. phaseolina was procured from the Culture Collection of the Department of Botany and Microbiology, Gurukula Kangri Vishwavidyalaya, Haridwar (India) (Singh et al., 2010). Antagonistic properties of bacterial isolates were tested against M. phaseolina on potato dextrose agar (PDA) plates following the dual culture technique of Skidmore and Dickinson (1976). Five days old mycelial discs of $5 \mathrm{~mm}$ diameter were placed in the center of solidified medium in plates containing modified PDA by adding $2 \%$ sucrose. Culture of isolate Bacillus sp. BS14 $\left(7 \times 10^{6} \mathrm{cfu} \mathrm{ml}^{-1}\right)$ was spotted $2 \mathrm{~cm}$ apart from the fungal disc and incubated at $28 \pm 1^{\circ} \mathrm{C}$ for 5 days. Growth inhibition was calculated by measuring the distance between the bacterial and fungal colonies as compared to the control. The fungal growth inhibition (\%) was calculated by using the formula: $100 \times \mathrm{C}-\mathrm{T} / \mathrm{C}$, 
where $\mathrm{C}=$ radial growth of fungus in control and $\mathrm{T}=$ radial growth of fungus in dual culture. Purified biosurfactant of isolate BS14 was used to check the fungal growth inhibition by Agar well diffusion assay (Nalini and Parthasarathi, 2014).

\subsection{Post-interaction events}

Fungal mycelia growing towards the zone of interaction were processed for scanning electron microscopic (SEM), available at Wadia Institute of Himalayan Geology, Dehradun. Agar discs of $1 \mathrm{~mm}$ thickness were cut from the zone of interaction and placed on cover glasses. These were treated with $2 \%$ glutaraldehyde solution at $20^{\circ} \mathrm{C}$ for 24 h. Electron microscopic study was done at Wadia Institute of Himalayan Geology, Dehra Dun (India). The samples transferred to copper stubs over double adhesive tape were coated with gold in POLARON, AU/PD sputter coater, and scanned by SEM at $30 \mathrm{kV}$.

\subsection{Chemical characterization of biosurfactant}

\subsubsection{Fourier transform-infrared spectroscopy (FT-IR) spectra of the dried biosurfactant}

FT-IR spectra of the dried biosurfactants were recorded on an 8400S, FT-IR spectrometer (Shimadzu), available at Patanjali Research Institute, Haridwar, and equipped with a mercury-cadmium-telluride (MCT) detector and cooled with liquid nitrogen. About $2 \mathrm{mg}$ of dried biomaterial was milled with $200 \mathrm{mg}$ of $\mathrm{KBr}$ to form a very fine powder. The powder was compressed into a thin pellet to be analyzed by FT-IR spectra measurement in wavelength of $400-4000 \mathrm{~cm}^{-1}$. The analysis of FT- IR spectra was carried out by using OPUS 3.1 (Bruker Optics) software.

\subsubsection{Gas chromatography-mass spectroscopy (GC-MS) analysis}

GC-MS analysis of biosurfactant was done by using a Varian 4000 Mass Spectrometer employing DB5 type capillary column and helium as a carrier gas at a flow rate of $0.5 \mathrm{ml} / \mathrm{min}$. The sample volume was $1 \mu 1$ and the temperature was gradually increased from $40^{\circ} \mathrm{C}$ to $280^{\circ} \mathrm{C}$ to identify the compound. The total run time was 45 min. The MS transfer line was maintained at a temperature of $280^{\circ} \mathrm{C}$. GC-MS analysis was done using electron impact ionization at $70 \mathrm{eV}$ and data were evaluated using total ion count (TIC) for identification and quantification of the compound. A comparative study was done between the identified compound spectra and that of known compounds of the GC-MS library NIST.

\subsection{Pot trial experiments}



Pathology Department, IARI, Delhi, India) per pot randomly in the rabi season from November to April. A total of 5 treatments were used during pot trials. Treatment 1 was seed dressing with antibiotic-resistant marker strain of Bacillus sp. BS14 ${ }^{\mathrm{Cam}+\mathrm{Ery}+}$. For this, healthy socked in lukewarm water overnight and used for seeds biopriming (Dubey et al. 2012). Treatment 2 was designed by infesting the seeds of $V$. mungo with sclerotia of $M$. phaseolina by mixing $0.5 \mathrm{mg}$ sclerotia in $1 \% \mathrm{CMC}$ or bio-priming. Treatment 3 was a mix of treatment 1 and treatment 2 . In treatment 4 crude biosurfactant in 1\% CMC (1:1) (for seed bacterization) was used. For Treatment 5, treatment 2 was mixed with treatment 4. Non-bacterized seed acted as a control. Antibiotic marker strain of Bacillus sp. BS14 was following the method of Dheeman et al. (2020) using Chloramphenicol and Erythromycin. After all treatments, seeds were sown in sterile pots in triplicates. Rhizospheric soil was sampled and monitored for root colonization from the bacterial treatment for estimation of Bacillus sp. BS14 ${ }^{\mathrm{Cam}+\mathrm{Ery}+}$ and indigenous native bacteria at 30, 60, and 90 days after sowing (DAS). Bacillus sp. BS14 ${ }^{\mathrm{Cam}+\mathrm{Ery}+}$ strain colonizing V. mungo roots was screened on chloramphenicol and erythromycin amended medium. Seed germination and plant growth parameters, such as root/shoot (length) weight (dry/fresh) were measured. As a sample ten fungus-infested plants were taken out after 60 days after plantation and symptoms (defoliation and wilting) of charcoal rot disease in plant roots were measured.

\subsection{Statistical analysis}

197

The data were analyzed statistically for the mean differences in values of control and treated plants using Microsoft excel and Graph pad prism 5.0 software. The data were subjected to one-way analysis of variance (ANOVA) to determine the effect of treatment conditions, period, and their interaction on various parameters. The data were analyzed employing the Duncan's Multiple Range Test (DMRT) by taking $p \leq 0.01$ as a significant level.

\section{Results}

\subsection{Isolation of putative Bacillus}

Based on morphological, physiological, and biochemical characteristics the isolates were found Gram-positive, rod-shaped endospore former, and producers of white, dry and folds, opaque and irregular edged colonies on NAM plates. Eight isolates positively produced catalase, oxidase, and glucose, and were negative for $\mathrm{H}_{2} \mathrm{~S}$ production, methyl red, glucosamine, and sorbose (Supplementary Table 1).

\subsection{Screening of biosurfactant}


Eight isolates were screened for biosurfactant production by carrying out several tests. All the isolated exhibited

209

210

211

212

213

214

215

216

217

218

219

220

221

222

223

224

225

226

227

228

229

230

231

232 positive $\beta$-hemolytic activity, BATH assay, drop collapse test, oil spreading assay, emulsification assay, and surface tension assay. All the isolates except BS21 and BS24 displayed positive CTAB-methylene blue agar plate assay. Among all the isolates BS14 was found to show the best biosurfactant producing properties (Table 1).

A dark blue halo zone with a sharply defined edge around the culture well was observed after $24 \mathrm{~h}$ in CTABmethylene blue agar assay. In BATH assay, the bacterial cells indicated their affinity towards the hydrophobic substrate. BS14 showed $\beta$-hemolysis displaying the maximum hemolytic zone of $\sim 2.94 \mathrm{~cm}$. Cell adherence of BS14 to crude oil was $80.23 \%$. Emulsification assay is an indirect method used to screen biosurfactant production. The cell-free culture broth of BS14, BS24, BS27, and BS41 showed more emulsification activity with petrol oil than the other isolates. BS14 showed significant emulsification activity with the emulsification index $\left(\mathrm{E}_{24}\right)$ of 70.58. In contrast, BS27 and BS41 displayed a better drop collapse test than the other isolates. Furthermore, the isolates BS12 and BS14 showed the maximum reduction in surface tension by $67.14 \mathrm{D} / \mathrm{CM}$ than the other isolates. BS14, BS27, and BS41 showed the maximum oil spreading activity forming the clearing zone (Table 1).

\subsection{Plant growth-promoting (PGP) activities of isolates}

Eight Bacillus isolates produced IAA and solubilized phosphate, whereas BS12, BS14, BS24, and BS27 produced HCN. The development of pink color with and without tryptophan in cell-free supernatant indicated IAA production. Change in color of filter paper from yellow to moderate and reddish-brown by adding $\mathrm{FeCl}_{3}$ indicated HCN production by the isolates. Siderophore was produced only by BS12, BS14, BS28, BS40, and BS41. The formation of orange halos around the spots on CAS agar medium indicates siderophore production. However, all the isolates were solubilized phosphate. Formation of clear halos around bacterial spots in Pikovskaya's medium after $48 \mathrm{~h}$ displayed phosphate solubilization. Moreover, none of the isolates produced chitinase except BS12 and BS14 (Table 2). All the isolates exhibited biofilm formation except BS12, BS40, and BS41. Bacterial cells adhered to the surface of test tubes which showed biofilm production.

\subsection{Molecular Identification}

The 16S rRNA gene sequence of the BS14 incorporated 1425bp (NCBI GenBank Accession No. KU991962). It showed 98\% sequence similarity with Bacillus cereus strain Ks6-15 and Bacillus cereus strain X9. Therefore, the isolate BS14 has further been referred to as Bacillus sp. BS14.

\subsection{In vitro Antagonistic activity of Bacillus sp. BS14 and pure biosurfactant}



and $53.6 \%$, respectively after 7 days of incubation at $28 \pm 1{ }^{\circ} \mathrm{C}$ (Fig. 1A; B). However, fungal inhibition was more pronounced in dual culture as compared to that of pure biosurfactant. Further, fungal growth inhibition corresponded with the incubation period.

\subsection{Post-interaction events in mycelia of M. phaseolina}

Bacillus sp. BS14 in the zone of interaction resulted in halo cell formation and caused mycelial deformities and hyphal degradation of M. phaseolina. Formation and development of M. phaseolina sclerotia were arrested towards the zone of interaction; consequently, such mycelia and sclerotia lost their vigor. The SEM study shows the dissolution of fungal septa, hyphal fragmentation, and perforation in the cell wall of M. phaseolina (Fig. 2A, B, C).

\subsection{Chemical analysis of Biosurfactant}

247 The chemical structure of the purified biosurfactant from Bacillus sp. BS14 was preliminarily investigated using FT-IR spectroscopy. The peak at $1568.02 \mathrm{~cm}^{-1}$ indicates the chemical structure identical to that of a cyclic compound consisting of a hexane ring. The peak at $2329.85 \mathrm{~cm}^{-1}$ indicates the Si-H group. The peak between 3394.48 and $3558.42 \mathrm{~cm}^{-1}$ shows the relatedness of the $\mathrm{Si}-\mathrm{NH}_{2}$ group. The FT-IR analysis shows the similarity with the cyclic compound produced by Bacillus sp. BS14 (Fig. 3). FTIR responsiveness within different absorption regions, absorbance peak heights corresponding to the $\mathrm{Si}-\mathrm{O}$ bond and $\mathrm{Si}-\mathrm{CH} 3$ bond were evidenced and indicated a strong correlation with the expected concentration in the siloxane. For external verification of the calibration, FTIR results were compared to those produced by GC-MS. The GC-MS analysis of the concentrated methanol extract resulted in many compounds. The peaks in the chromatogram were integrated and were compared with the database of the spectrum of known components stored in the GC-MS library of NIST to confirm the FT-IR structure analysis. Based on GC-MS analysis, the compound showed the relatedness with cyclic compound 'cyclic siloxane' (Fig. 4).

\subsection{Pot trial experiments}

260 Germination was enhanced maximally by the treatment of Bacillus sp. BS14, while the germination was significantly decreased in the fungal infested followed by mixed treatment of fungi and Bacillus BS14. Following the pattern of robustness, treatment BS14 evidence approximate 25\% enhancement in shoot length over control but, significantly lower in the fungal treatment after 90 days of sowing. It is also evidence that the disease severity 
index was reached at a peak in the fungal infestation. The development of roots can never be ignored as the attained maximum length in the bacteria treatment similar to the biosurfactant treatment. Enhancement in the shoot weight was observed high in the bacterial treatment again, but the biosurfactant treatment was equally effective in improving plant biomass. Bacillus sp. BS14 ${ }^{\mathrm{Cam}+\mathrm{Ery}+}$ strain successfully colonized V. mungo roots both in control and M. phaseolina-untreated pots and significantly $(\mathrm{p}<0.01)$ enhanced seed germination, plant growth, and plant biomass over control. (Table 3). Bacillus sp. BS14 $4^{\mathrm{Cam}+\mathrm{Ery}+}$ plus M. phaseolina inoculation displayed disease reduction at 30,60, and 90 days (DAS). Biosurfactant was able to reduce disease severity index but, not directly support plant growth promotion as compared to bacterial inoculation (Table 3). Bacillus sp. BS14 ${ }^{\mathrm{Cam}+\mathrm{Ery}+}$ displayed effective root colonization of $V$. mungo as evidenced by the recovery of significant bacteria population from V. mungo rhizosphere 90 DAS (Table 4).

\section{Discussion}

Baliyan et al. (2018) reported that rhizobacteria in the ecological population create a heterogeneous group of bacteria in the rhizosphere. Biosurfactant-producing Bacillus with plant growth-promoting traits as a rationale of this study can prove a better alternative for biocontrol agents of phytopathogens, bio-inoculants for plant growth, and crop yield enhancer in eco-balanced ways as compared to the other surfactant (Bais et al. 2004). In this study, Bacillus sp. BS14 was found the most doable biosurfactant producing plant growth-promoting rhizobacteria among the other eight isolates. BS14 can establish a new functional niche in the rhizosphere or soil habitat, as able to produce biosurfactants and indigenous farms soil. We observed that, culture filtrate of Bacillus sp. BS14 contains many plant growth-promoting compounds, such as IAA, chitinase, siderophore, and volatile compounds. Earlier, Bacillus is reported to bear a PGPR's characteristics, as evidence in our study (Kumar et al. 2012). In this trend, plant hormones like indole-3-acetic acid (IAA), gibberellins, cytokinins, and certain volatiles have also been reported in PGPRs (Mehta et al. 2010). Bacillus has been significant effects on the biocontrol of phytopathogenic fungi. (Dheeman et al. 2020). Similarly, BS14 is effective to restrict the growth of phytopathogenic fungi, under this investigation. On the other hand, phosphorus $(\mathrm{P})$ is a very crucial plant growthlimiting nutrient and available in insoluble form in a substantial amount in the soils for plant growth nutrient. The abilities of BS14 in phosphate solubilization was observed, as an important trait of PGPR. Also, Prakash and Arora (2019) evidenced the abilities of Bacillus for solubilization of phosphate and other mineral nutrients. Still, 
underscored. Further, this study opens a scope to utilize bacterial origin surfactant for soil remediation and enhancement of soil nutrition capacity.

In this sequence, another mineral, iron is a crucial nutrient for almost all forms of life and all microorganisms require iron for their growth and metabolism too (Neilands 1995). Bacillus sp. BS14 was found a prominent siderophore-producing bacterium in vitro, producing it can manage iron for their and plants' growth. Many rhizobacteria have been reported to produce antifungal metabolites like HCN (Bhattacharyya and Jha 2012). Production of HCN by Bacillus species has earlier been reported by Chen et al. (2010). In the present study, Bacillus sp. BS14 shown HCN production, has earlier been reported by Dheeman et al. (2020). BS14 produced a clear zone in the chitin-containing growth medium and showed chitinase producing abilities, as desired mechanisms of the biocontrol agent (Kumar et al. 2012). Chitinase production by rhizospheric bacilli from rice (Chen et al. 2010) and Phaseolus vulgaris (Kumar et al. 2012) has been reported earlier. Biosurfactant produced by Bacillus sp. BS14 showed antifungal activity against M. phaseolina. Mnif et al. (2015) isolated Bacillus sp. SPB1 produced a lipopeptide biosurfactant and exhibited antifungal activity against Rhizoctonia bataticola and Rhizoctonia solani. Cyclic siloxanes are very important and valuable compounds from the industrial application point of view. The cyclic siloxanes are used in the manufacture of silicones, carriers, lubricants, and solvents in a variety of commercial applications (Si 2006).

In the present investigation, biosurfactant produced by the strain Bacillus sp. BS14 showed structural similarity with the cyclic siloxanes. Extracellular polysaccharide plays a crucial role in silica release, especially in the case of quartz. Such polysaccharides can react with siloxanes to form organic siloxanes. It can be of bacterial provenance (e.g., from B. mucilaginosus var. siliceous; Avakyan et al. 1986). Strains of Bacillus thuringiensis $(B t)$ produce crystalline proteins ( $\delta$-endotoxins) during their stationary phase of growth. Many authors used surfactants (1,2-benzisothiazolin-3-one), of the inert ingredients in Foray 48 B; the siloxane (organosilicone) Triton- X-100, Tween 20, and Latron CS-7 as surfactants for Btk formulations (Helassa et al. 2009). Biofilm is a matrix structure of cells adhered to a surface and encased in extracellular polymeric substances. (Bogino et al. 2013). In the present study, Bacillus sp. BS14 produced biosurfactants and formed biofilm. The best biofilmforming activity was found in other isolates also those produce biosurfactants too. Biosurfactants are also known to play multifarious roles in biofilm-formation.

Beneficial rhizobacteria can promote plant growth not only by facilitating mineral nutrient uptake and phytohormone production but also more indirectly by protecting against the infection of fungal pathogens. They 
can antagonize pathogens by producing low-molecular-weight toxin or extracellular lytic enzymes (Haas and Keel 2003) and more indirectly by triggering the defensive capacities in the host plant (Cameotra and Makkar 2004). We found that Bacillus sp. BS14 inhibited the growth of M. phaseolina in vitro and resulted in several types of abnormalities in mycelia. It may be due to the secretion of many inhibitory compounds leading to multifarious abnormalities in fungal hyphae as observed by scanning electron microscopy (SEM). Similar work on biocontrol of M. phaseolina has been carried out by Kumar et al. (2012) Furthermore, fungal inhibition was more pronounced in dual culture as compared to pure biosurfactant

Pot trial experiments illustrated the potential of Bacillus sp. BS14 to be developed as an effective commercial biological control agent. Bacterial broth culture of Bacillus sp. BS14 ${ }^{\mathrm{Cam}+\mathrm{Ery}+}$ effectively enhanced plant growth and decreased charcoal rot disease. Effect of cyclic siloxane biosurfactant was observed in disease reduction irrespective of a direct impact on plant growth promotion. This may due to living actions and the involvement of other traits of bacteria in the rhizosphere. Thus Bacillus sp. BS14 played a great role in declining charcoal-rot disease along with plant growth promotion of V. mungo. Earlier, Bacillus spp. has been reported for the biological control of fungi including species of Fusarium, and Macrophomina (Cavagliery et al. 2005; Kumar et al. 2012). The capacious spectrum antagonistic activity of bacilli is executed by the secretion of several metabolites including antibiotics (Haas and Keel 2003), volatile HCN (Chen et al. 2010). and siderophores (Gupta et al. 2002).

As per evidence from the results obtained above, the isolate was putative to produce biosurfactants which already been reported by various scientists (Ayed et al. 2019; Nalini et al., 2020; Khedher et al. 2020), but still in its infancy, besides bacteria were able to show biosurfactant production as an indirect approach, similar to enzyme production, antibiotic production for biocontrol. Also, in the pot-trial, disease severity index was reduced significantly in the biosurfactant treatment, therefore, we postulate the effects of biosurfactant in biocontrol of $M$. phaseolina and their other PGP traits in plant growth promotion

\section{Conclusions}

Based on the above studies it may be concluded that biosurfactant-producing bacteria are also available in the rhizosphere of legume crops. Bacillus sp. BS14 of our study exhibited strong plant growth-promoting properties and biocontrol potential against M. phaseolina causing charcoal rot in V. mungo further explore the use of biosurfactants(s) or biosurfactant producing bacteria for biocontrol of charcoal rot disease. Future studies can 
include the production of bio inoculants in various carrier materials and further, use such bacteria in the production of bio inoculants is a future requirement of agricultural and environmental sustainability.

\section{References}

Agarwal M, Dheeman S, Dubey RC, Kumar P, Maheshwari DK, Bajpai VK (2017) Differential antagonistic responses of Bacillus pumilus MSUA3 against Rhizoctonia solani and Fusarium oxysporum causing fungal diseases in Fagopyrum esculentum Moench. Microbiol Res 205:40-47

Al-Ali A, Deravel J, Krier F, Béchet M, Ongena M, Jacques P (2018) Biofilm formation is determinant in tomato rhizosphere colonization by Bacillus velezensis FZB42. Environ Sci Poll Res 25(30):29910-29920

Arora NK, Kang SC, Maheshwari DK (2001) Isolation of siderophore-producing strains of Rhizobium meliloti and their biocontrol potential against Macrophomina phaseolina that causes charcoal rot of groundnut. Curr Sci 673-677

Avakyan ZA, Pivovarova TA, Karavaiko GI (1986) Properties of new species Bacillus mucilaginosus. Mikrobiologiya 55:477-482

Ayed HB, Azabou MC, Hmidet N, Triki MA, Nasri M (2019) Economic production and biocontrol efficiency of lipopeptide biosurfactants from Bacillus mojavenis A21. Biodegradation 30(4):273-286

Bais HP, Fall R, Vivanco JM (2004) Biocontrol of Bacillus subtilis against infection of Arabidopsis roots by Pseudomonas syringae is facilitated by biofilm formation and surfactin production. Plant Physiol 134(1):307-319

Bakker AW, Schippers B (1987) Microbial cyanide production in the rhizosphere in relation to potato yield reduction and Pseudomonas spp. mediated plant growth-stimulation. Soil Biol Biochem 19:451-457

Baliyan N, Dheeman S, Maheshwari DK, Dubey RC, Vishnoi VK (2018) Rhizobacteria isolated under field first strategy improved chickpea growth and productivity. Environ Sustain 4: 461-469.

Bee H, Khan MY, Sayyed RZ (2019) Microbial surfactants and their significance in agriculture. In: Plant Growth Promoting Rhizobacteria (PGPR): Prospects for Sustainable Agriculture, Springer, Singapore. pp. 205-215

Bhattacharyya PN, Jha DK (2012) Plant growth-promoting rhizobacteria (PGPR): Emergence in agriculture. World J Microbiol Biotechnol 28:1327-1350 

components in plant-bacterial associations. Int J Mol Sci 14:15838-15859 molecules. Curr Opin Microbiol 7:262-266

Chen F, Wang M, Zheng Y, Luo J, Yang X, Wang X (2010) Quantitative changes of plant defense enzymes and phytohormone in biocontrol of cucumber Fusarium wilt by Bacillus subtilis B579. World J Microbiol Biotechnol 26(4):675-684

Das P, Mukherjee S, Sen R (2008) Improved bioavailability and biodegradation of a model polyaromatic hydrocarbon by a biosurfactant producing bacterium of marine origin. Chemosphere 72(9):1229-1234

De Freitas JR, Banerjee MR, Germida JJ (1997) Phosphate-solubilizing rhizobacteria enhance the growth and yield but not phosphorus uptake of canola (Brassica napus L.). Biol Fertil Soil 24(4):358-364 competitive rhizosphere and non-rhizosphere Bacillus in plant growth promotion and yield improvement of Eleusine coracana (Ragi). Can J Microbiol 66(2):111-124

Dubey RC, Maheshwari DK (2012) Practical Microbiology. S. Chand \& Company Pvt. Ltd., Ram Nagar, New Delhi - 55, India, p. 640.

Dubey RC, Maheshwari DK, Kumar V, Pandey RR (2012) Growth enhancement of Sesamum indicum L. by rhizosphere-competent Azotobacter chroococcum AZO2 and its antagonistic activity against Macrophomina phaseolina. Arch Phytopathol Plant Protec 45:437-454

Dunne C, Crowley JJ, Moënne-Loccoz Y, Dowling DN, O'Gara F (1997) Biological control of Pythium ultimum by Stenotrophomonas maltophilia W81 is mediated by an extracellular proteolytic activity. Microbiology 143:3921-3931

Gupta C, Dubey R, Maheshwari DK (2002) Plant growth enhancement and suppression of Macrophomina phaseolina causing charcoal rot of peanut by fluorescent Pseudomonas. Biol Fertil Soil 35(6):399-405 phaseolina causing charcoal rot of peanut by fluorescent Pseudomonas. Biol Fertil Soil 35:399-405 

for biological control of plant disease. Ann Rev Phytopathol 41:117-153

402 Hafeez FY, Naureen Z, Sarwar A (2019) Surfactin: An emerging biocontrol tool for agriculture sustainability. In: Plant Growth Promoting Rhizobacteria for Agricultural Sustainability, Springer, Singapore. pp. 203-213

404 Hänsel R, Kruse D, Sieverding E, Riedl C, Ludwig JS (2019) Use of polyether modified short-chain siloxanes in 405 agriculture in order to increase harvest yield. US Patent Application No. 16/073,091

406 Helassa N, Quiquampoix H, Noinville S, Szponarski W, Staunton S (2009) Adsorption and desorption of mono407 meric Bt (Bacillus thuringiensis) Cry1 Aa toxin on mont- morillonite and kaolinite. Soil Biol Biochem 41:498$408 \quad 504$

411 Holt JG, Krieg NR, Sneath PHA, Staley JT (1994) Bergey's manual of determinative bacteriology. Ed. $9^{\text {th }}$.

412 Baltimore. The Williams and Wilkins Co. ISBN 0-683-00603-7, p. 787

413 Jain DK, Collins-Thompson DL, Lee H, Trevors TA (1991) Drop collapsing test for screening surfactant414 producing microorganisms. J Microbiol Method 13:271-279

415 Khalili E, Javed MA, Huyop F, Rayatpanah S, Jamshidi S, Wahab RA (2016) Evaluation of Trichoderma isolates 416 as potential biological control agent against soybean charcoal rot disease caused by Macrophomina 417 phaseolina. Biotechnol Biotechnolgic Equip 30(3):479-488

418 Khedher SB, Boukedi H, Laarif A, Tounsi S (2020) Biosurfactant produced by Bacillus subtilis V26: a potential 419 biological control approach for sustainable agriculture development. Organ Agric e1-8 
422 Springer Netherlands, pp. 91-111

423 Kumar P, Dubey RC, Maheshwari DK (2012) Bacillus strains isolated from rhizosphere showed plant growth promoting and antagonistic activity against phytopathogens. Microbiol Res 167:493-499

Kumar S, Dubey RC, Maheshwari DK (2016) Biosurfactant-mediated biocontrol of Macrophomina phaseolina Causing Charcoal Rot in Vigna mungo by a Plant Growth Promoting Enterococcus sp. BS13. J Plant Pathol Microbiol 7(385):2

Lunkenheimer K, Wantke KD (1981) Determination of the surface tension of surfactant solutions applying the method of Lecomte du Noüy (ring tensiometer). Coll Poly Sci 259:354-366 Business Media.

Mnif I, Mnif S, Sahnoun R, Maktouf S, Ayedi Y, Ellouze-Chaabouni S, Ghribi D (2015) Biodegradation of diesel oil by a novel microbial consortium: comparison between co-inoculation with biosurfactant-producing strain and exogenously added biosurfactants. Environ Sci Poll Res 22:14852-14861

Nalini S, Parthasarathi R (2014) Production and characterization of rhamnolipids produced by Serratia rubidaea 

Macrophomina phaseolina isolated from three legume crops and evaluation of mungbean genotypes for resistance to dry root rot. Crop Protec 127:104962

Pandya U, Saraf M (2015) Isolation and identification of allelochemicals produced by B. sonorensis for suppression of charcoal rot of Arachis hypogaea L. J Basic Microbiol 55:635-644 of Mentha arvensis L. 3 Biotech 9(4):126

Rodrigues LR, Teixeira JA, vanderMei HC, Oliveira R (2006) Physicochemical and functional characterization of a biosurfactant produced by Lactococcus lactis 53. Coll Surf B: Biointer 49:79-86 amyloliquefaciens strain BO5A. J Nat Prod 76:2019-2025 Press, Long Island, NY, USA. a dirhamnolipid biosurfactant secreted by Pseudomonas aeruginosa in aqueous media. J Coll Inter Sci 307:246253

Sarwar A, Brader G, Corretto E, Aleti G, Abaidullah M, Sessitsch A, Hafeez FY (2018b) Qualitative analysis of activity of surfactin A purified from Bacillus NH-100 and NH-217 against rice bakanae disease. Microbiol Res 209:1-13 biosurfactants and bioemulsifiers: A Review. Crit Rev Biotechnol 30:127-144 
471 Schwyn B, Neilands JB (1987) Universal chemical assay for the detection and determination of 472 siderophores. Anal Biochem 160:47-56

473 Shahid S, Khan MR (2019) Evaluation of biocontrol agents for the management of root-rot of mung bean caused

474 by Macrophomina phaseolina. Indian Phytopathol 72(1):89-98

475 Si O (2006) Need to assess efficacy of public health actions. In: Meeting of the California Environmental 476 Contaminant Biomonitoring Program (CECBP) Scientific Guidance Panel (SGP) Dec. 4-5.

477 Siegmund I, Wagner F (1991) New method for detecting rhamnolipids excreted by Pseudomonas species during 478 growth on mineral agar. Biotechnol Tech 5:265-268

479 Singh N, Kumar S, Bajpai VK, Dubey RC, Maheshwari DK, Kang SC (2010) Biological control of 480 Macrophomina phaseolina by chemotactic fluorescent Pseudomonas aeruginosa PN1 and its plant growth 481 promotory activity in chir-pine. Crop Protec 29(10):1142-1147

482 Singh R, Kumar M, Mittal A, Mehta PK (2017) Microbial metabolites in nutrition, healthcare and 483 agriculture. 3Biotech 7(1):15

484 Skidmore AM, Dickinson CH (1976) Colony interactions and hyphal interference between Septoria nodorum and 485 phylloplane fungi. Trans British Mycol Soc 66:57-64

486 Sriram MI, Kalishwaralal K, Deepak V, Gracerosepat R, Srisakthi K, Gurunathan S (2001) Biofilm inhibition and 487 antimicrobial action of lipopeptide biosurfactant produced by heavy metal tolerant strain Bacillus cereus NK1. Coll Surf B:Biointer 85:174-181 detect biosurfactant production by diverse microorganisms. J Microbiol Method 56:339-347 
Fig. 1 Antagonistic effect of (A) Bacillus sp. BS14 against M. phaseolina in dual culture media (B) purified biosurfactant of Bacillus sp. BS14 against M. phaseolina in fungal culture media

495

496

497

498

499

500

501

502

503

504

505

506

Fig. 2 Scanning Electron Microscopy (SEM) showing post-interaction events in the hyphae and sclerotia of $M$. phaseolina caused by Bacillus sp. BS14; (A) Control; (B) hyphal lysis and cell shrinkage; (C) loss of vigour and mycelia fragmentation; (D) hyphal fragmentation, shrinkage, loss of vigour, and loss of sclerotia integrity

Fig. 3 FTIR spectroscopy analysis of biosurfactant produced by Bacillus sp. BS14

Fig. 4 GC-MS spectra of purified biosurfactant produced by Bacillus sp. BS14.

\section{Legends Table}

Table 1 Biosurfactant producing assays of rhizospheric bacilli from Vigna mungo

Table 2 Plant growth promoting attributes, chitinase production and biofilm assay of rhizospheric bacilli from V. mungo in vitro

Table 3 Effect of cyclic siloxane biosurfactant and Bacillus sp. BS14 ${ }^{\mathrm{Cam}+\mathrm{Ery}+}$ under various treatments on the growth of $V$. mungo under pot assays after 90 days

Table 4 Root colonization of V. mungo by Bacillus sp. strain BS14 ${ }^{\mathrm{Cam}+\mathrm{Ery}+}$ at 30, 60 and 90 days 


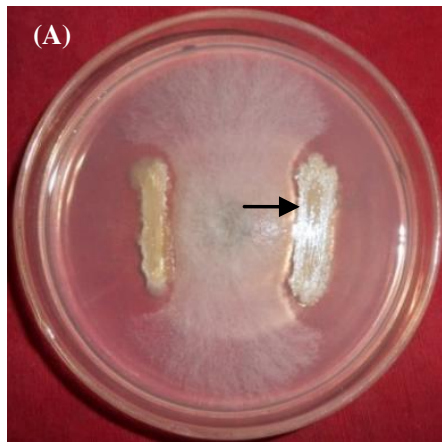

(B)

509

Fig. 1

510 


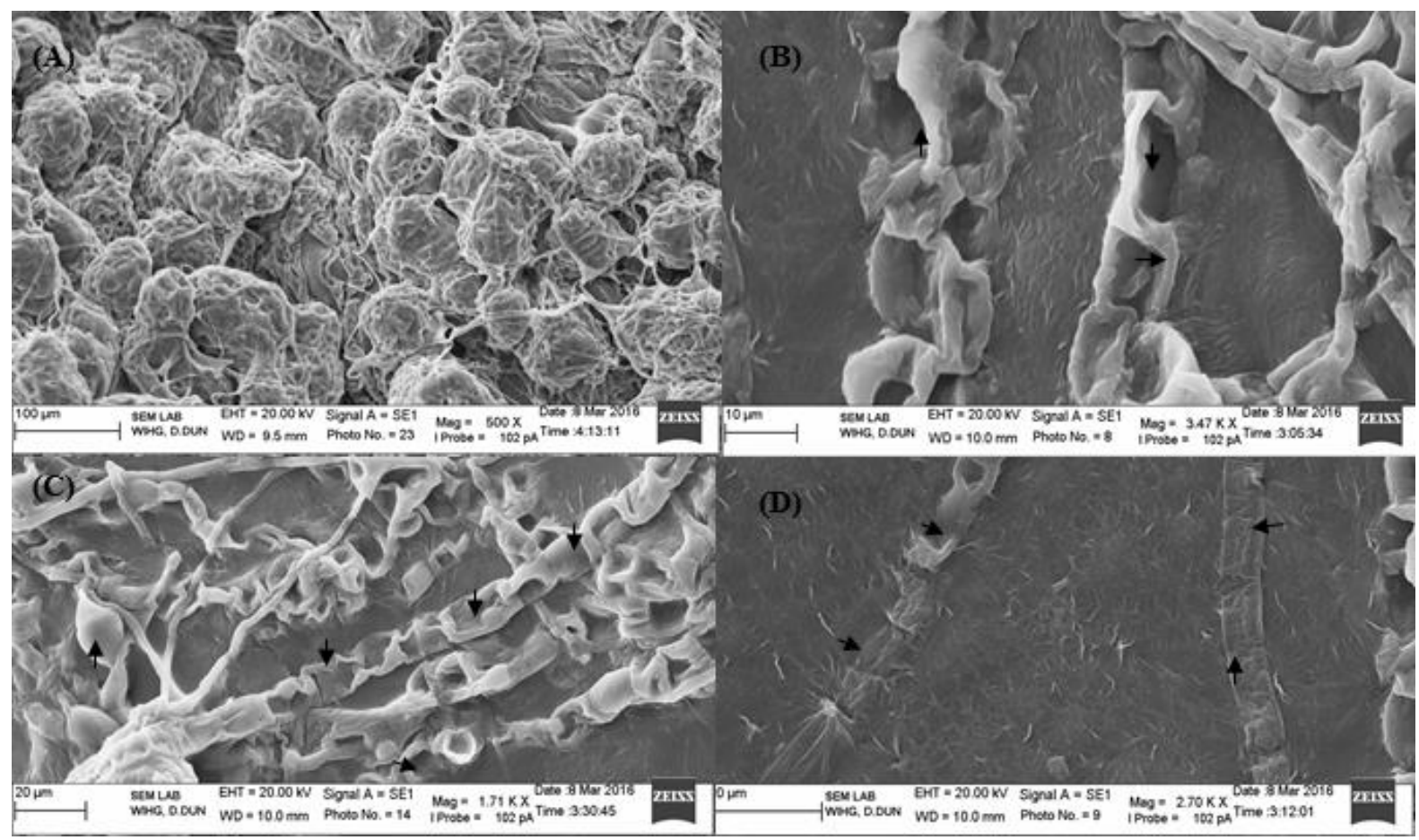

512 Fig. 2 


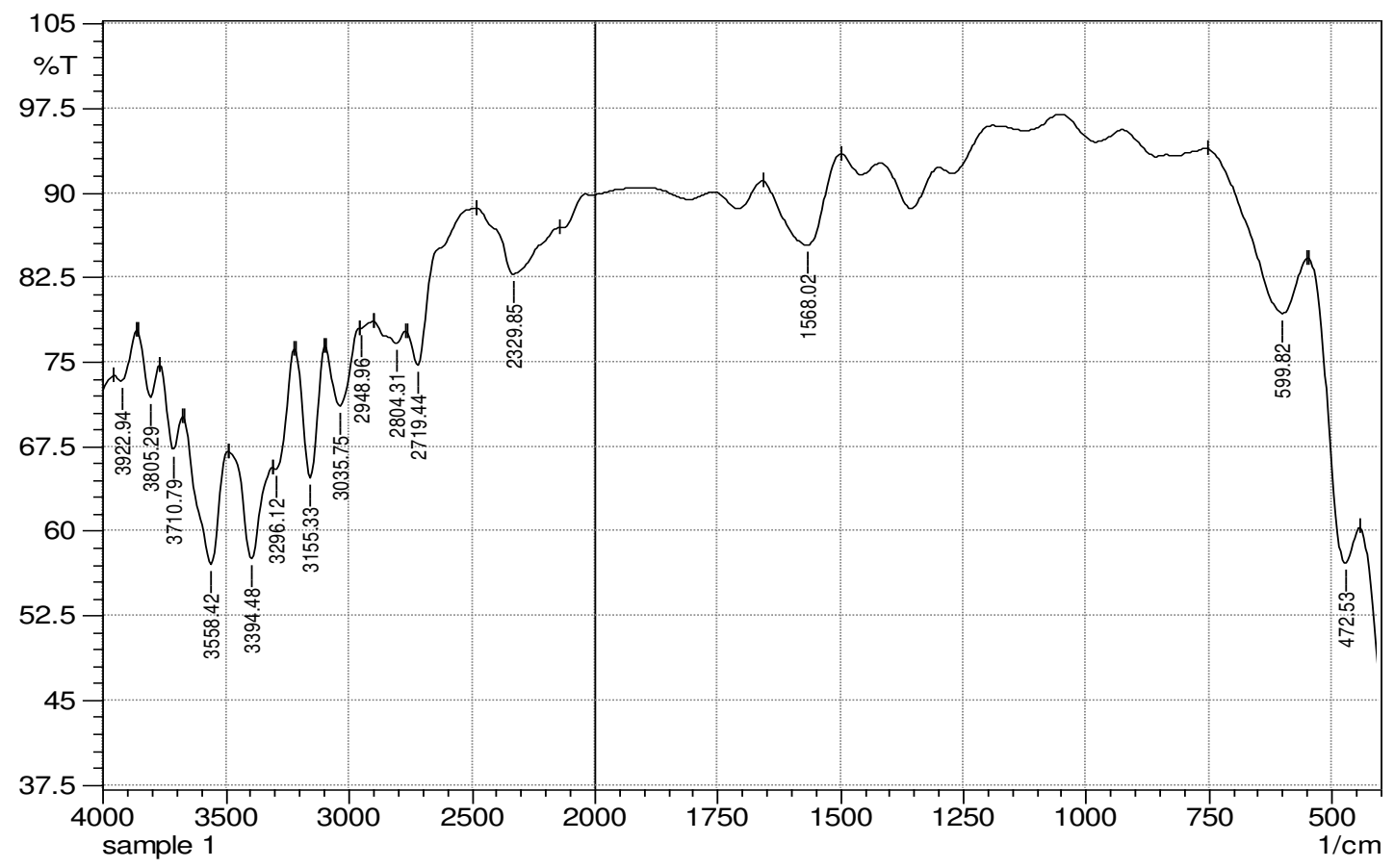

525

Fig. 3

526 


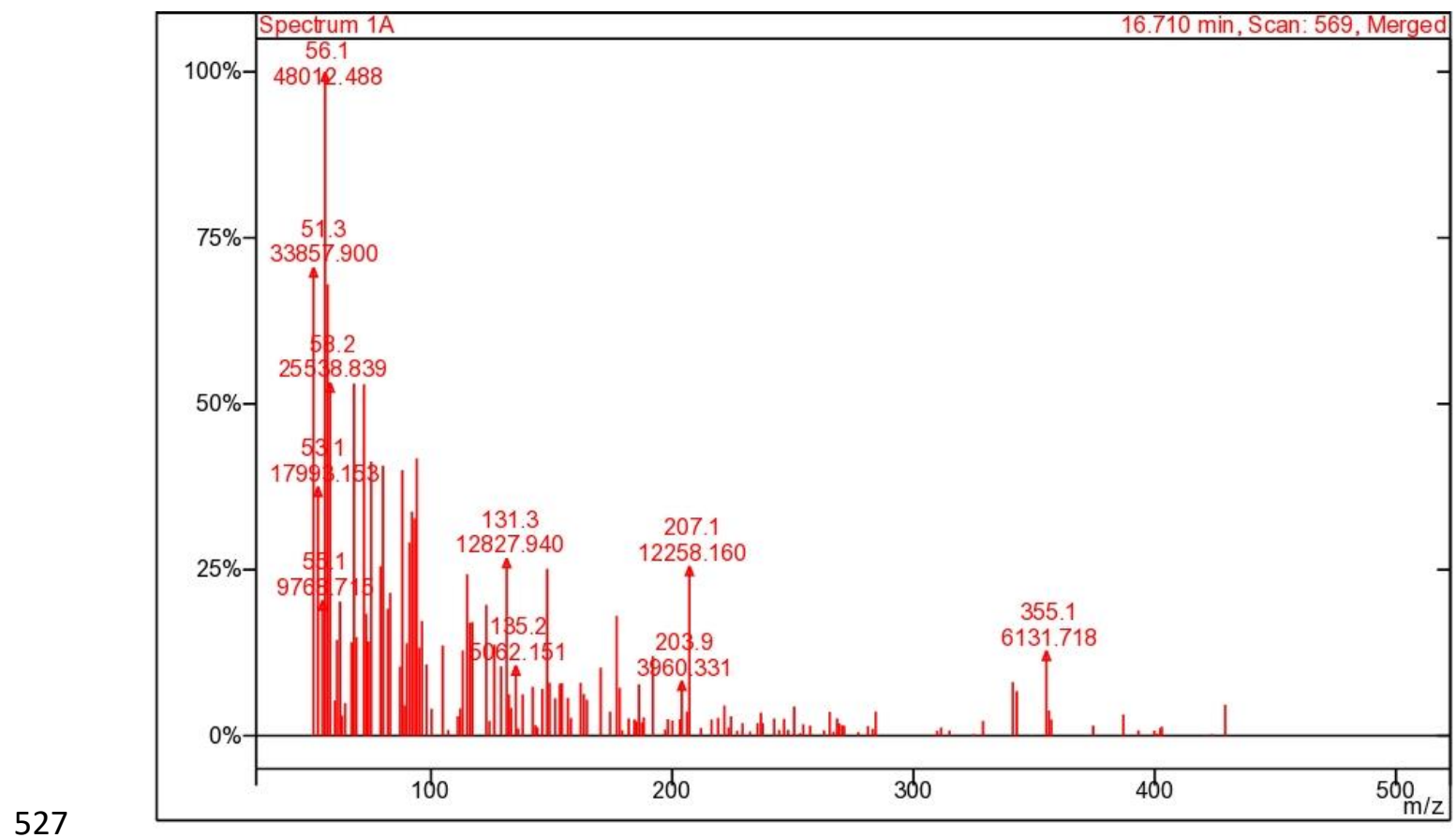

$528 \quad$ Fig. 4 


\begin{tabular}{|c|c|c|c|c|c|c|c|}
\hline Isolates & $\begin{array}{c}\text { CTAB methylene } \\
\text { blue agar plate } \\
\text { assay }\end{array}$ & $\begin{array}{c}\boldsymbol{\beta} \text {-hemolytic } \\
\text { activity }\end{array}$ & BATH assay & $\begin{array}{c}\text { Emulsification } \\
\text { assay }\end{array}$ & $\begin{array}{c}\text { Drop collapse test } \\
\text { Surface Tension } \\
\text { measurement } \\
\text { (D/CM) }\end{array}$ & $\begin{array}{c}\text { Oil spreading } \\
\text { assay }\end{array}$ \\
\hline BS12 & ++ & ++ & ++ & + & + & 52.12 & + \\
\hline BS14 & +++ & +++ & ++ & ++ & + & 67.14 \\
\hline BS21 & - & + & + & + & + & 31.23 & + \\
\hline BS24 & - & ++ & ++ & ++ & + & 28.32 & + \\
\hline BS27 & + & + & ++ & ++ & ++ & 32.31 \\
\hline BS28 & + & + & + & + & + & 21.12 & + \\
\hline BS40 & + & + & + & + & + & 40.13 & + \\
\hline BS41 & ++ & + & + & ++ & ++ & 24.12 & + \\
\hline
\end{tabular}


Table 2

\begin{tabular}{|c|c|c|c|c|c|c|}
\hline Isolates & Siderophore & $\mathrm{HCN}$ & IAA & Chitinase production & Phosphate solubilization & Biofilm assay \\
\hline BS12 & + & + & ++ & + & +++ & - \\
\hline BS14 & +++ & ++ & +++ & ++ & +++ & + \\
\hline BS21 & - & - & + & - & + & + \\
\hline BS24 & - & + & + & - & + & + \\
\hline BS27 & - & + & + & + & + & + \\
\hline BS28 & ++ & - & + & - & + & + \\
\hline BS40 & + & - & + & - & + & - \\
\hline BS41 & ++ & - & + & - & ++ & - \\
\hline
\end{tabular}

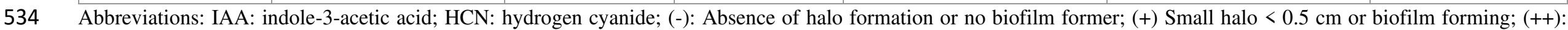

535 Medium halo formation $>0.5 \mathrm{~cm}$ wide surrounding to colonies; (+++) Large holo $>1.0 \mathrm{~cm}$ wide surrounding to colonies. 
Table 3

\begin{tabular}{|c|c|c|c|c|c|c|c|c|}
\hline \multirow[t]{2}{*}{ Treatments } & \multirow{2}{*}{$\begin{array}{l}\text { Germination } \\
(\%)\end{array}$} & \multirow{2}{*}{$\begin{array}{l}\text { Shoot } \\
\text { length } \\
\text { (cm) }\end{array}$} & \multirow{2}{*}{$\begin{array}{l}\text { Root length } \\
\text { (cm) }\end{array}$} & \multicolumn{2}{|c|}{ Shoot Weight } & \multicolumn{2}{|c|}{ Root Weight } & \multirow{2}{*}{$\begin{array}{l}\text { Disease } \\
\text { Severity } \\
\text { Index }\end{array}$} \\
\hline & & & & Fresh $(\mathrm{g})$ & Dry (g) & Fresh $(\mathrm{g})$ & Dry $(g)$ & \\
\hline Bacillus sp. BS14 ${ }^{\text {Cam+Ery+ }}$ & 93.3 & $49.0^{* *}$ & $19.0^{* *}$ & $5.530^{* *}$ & $0.954^{* *}$ & $1.932^{* *}$ & $0.090^{*}$ & 2.0 \\
\hline M.phaseolina & 53.3 & $31.8^{* *}$ & $11.4^{* *}$ & $3.329^{* *}$ & $0.710^{* *}$ & $0.754^{* *}$ & $0.066^{* *}$ & 9.0 \\
\hline $\begin{array}{l}\text { Bacillus sp.BS14 }{ }^{\mathrm{Cam}+\mathrm{Ery}+} \\
+ \text { M. phaseolina }\end{array}$ & 73.6 & $46.8^{* *}$ & $17.7^{* *}$ & $5.241^{* *}$ & $0.906^{* *}$ & $1.808^{* *}$ & $0.085^{* *}$ & 7.0 \\
\hline Biosurfactant (Pure) & 93.3 & $49.0^{* *}$ & $19.0^{* *}$ & $5.530^{* *}$ & $0.954^{* *}$ & $1.932^{* *}$ & $0.090^{* *}$ & 1.0 \\
\hline $\begin{array}{l}\text { Biosurfactant (Pure) + } \\
\text { M. phaseolina }\end{array}$ & 81.5 & $36.4^{* *}$ & $12.6^{* *}$ & $4.173^{* *}$ & $0.718^{* *}$ & $1.741^{* *}$ & $0.073^{* *}$ & 5.0 \\
\hline Control & 63.3 & 38.9 & 13.9 & 3.998 & $0.793^{* *}$ & 1.173 & 0.075 & 8.0 \\
\hline
\end{tabular}

Values are the mean of triplicates; ** significant at $1 \%$ level of LSD by two-way ANOVA. Duncan Multiple range test employed differentiate each parameter with different 


\begin{tabular}{|l|c|c|c|}
\hline \multirow{2}{*}{ Treatment } & \multicolumn{3}{|c|}{ Bacterial population (log cfu) } \\
\cline { 2 - 4 } & 30 days & 60 days & 90 days \\
\hline Bacillus sp. BS14 & $6.14 \pm 0.12$ & $7.22 \pm 0.17$ & $7.12 \pm 0.11$ \\
\hline Bacillus sp. BS14 & & & 7.11 \\
\hline
\end{tabular}

Values are the average of three replicates. Bar \pm represents standard deviation (SD) from the mean value. 
Supplementary Material

Cyclic siloxane biosurfactant producing Bacillus sp. BS14 biocontrol charcoal rot pathogen

Macrophomina phaseolina and induce growth promotion in Vigna mungo L.

Table 1

\begin{tabular}{|c|c|c|c|c|c|c|c|c|c|c|}
\hline Characteristics & $\underset{\mathscr{n}}{\mathfrak{n}}$ & $\underset{\mathscr{a}}{ \pm}$ & $\begin{array}{l}\text { ฟ్ } \\
\text { ڤึ }\end{array}$ & $\begin{array}{l}\text { ปี่ } \\
\text { ஸै }\end{array}$ & స్య & 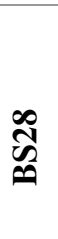 & 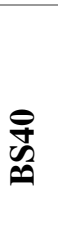 & $\underset{\mathscr{~}}{7}$ & 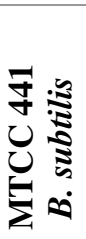 & 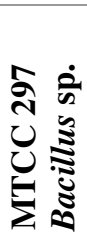 \\
\hline Gram Reaction & + & + & + & + & + & + & + & + & + & + \\
\hline Rod & + & + & + & + & + & + & + & + & + & + \\
\hline Endospore Former & + & + & + & + & + & + & + & + & + & + \\
\hline Motility & + & + & + & + & + & + & + & + & + & + \\
\hline Growth at $4^{\circ} \mathrm{C}$ & + & + & + & + & + & + & + & + & + & + \\
\hline at $45^{\circ} \mathrm{C}$ & - & - & - & + & - & - & + & - & - & - \\
\hline Growth in $4 \%$ Nacl & - & + & + & + & + & + & + & - & - & - \\
\hline $5 \%$ Nacl & + & + & + & + & + & + & + & + & + & + \\
\hline $6 \%$ Nacl & + & + & + & + & + & + & + & + & + & + \\
\hline $7 \% \mathrm{NaCl}$ & + & + & + & + & + & - & + & - & + & - \\
\hline Oxidase Reaction & - & - & - & + & - & + & - & - & - & + \\
\hline Catalase Reaction & + & + & + & + & + & + & + & + & + & + \\
\hline $\mathrm{H}_{2} \mathrm{~S}$ production & - & - & - & - & - & - & - & - & - & - \\
\hline Indole Production & - & - & - & - & - & - & - & - & - & - \\
\hline VP test & + & + & - & - & + & - & + & - & + & - \\
\hline Citrate utilization & + & + & + & + & + & + & + & + & + & + \\
\hline Lipid Hydrolysis & + & + & + & + & + & + & + & + & + & + \\
\hline Starch Hydrolysis & + & + & + & + & + & + & + & + & + & + \\
\hline Casein Hydrolysis & + & + & + & + & + & + & + & + & + & + \\
\hline Gelatine Hydrolysis & + & + & + & + & + & + & + & + & + & + \\
\hline Urease production & + & + & + & + & + & + & + & + & + & + \\
\hline
\end{tabular}

Abbreviations: (-): Absence of activity; (+): Presence of activity. 
Figures
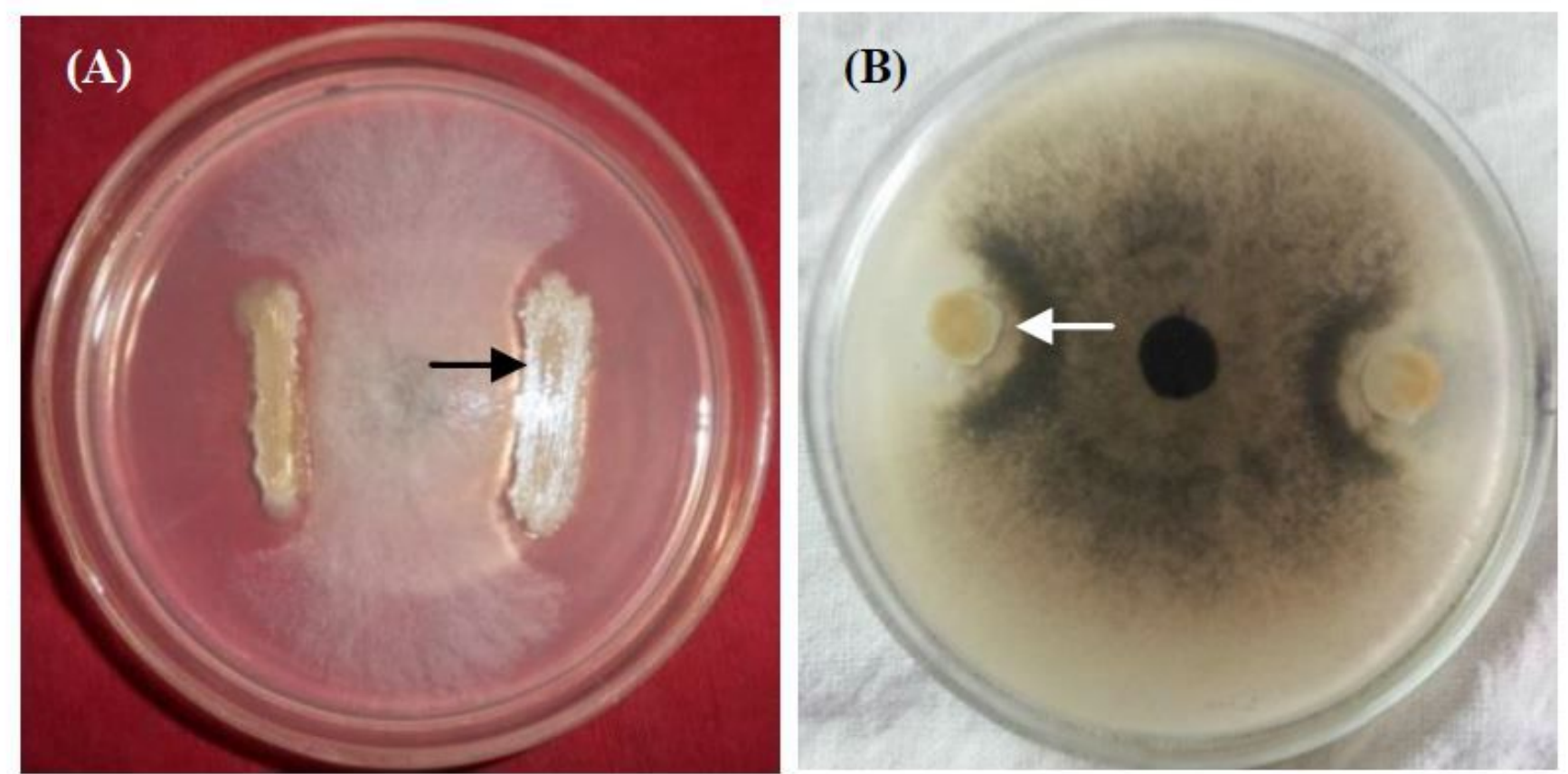

\section{Figure 1}

Antagonistic effect of (A) Bacillus sp. BS14 against M. phaseolina in dual culture media (B) purified biosurfactant of Bacillus sp. BS14 against M. phaseolina in fungal culture media 


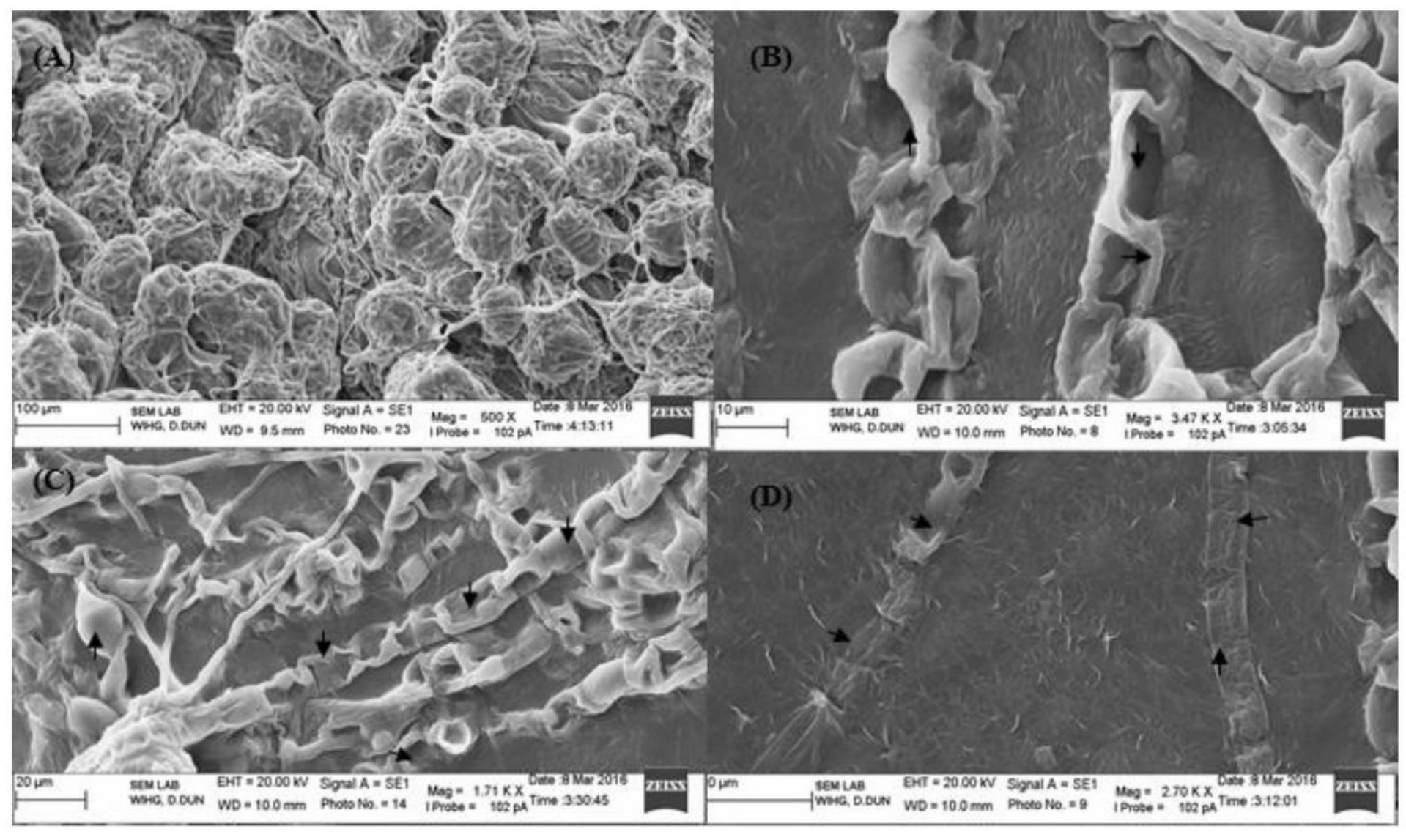

Figure 2

Scanning Electron Microscopy (SEM) showing post-interaction events in the hyphae and sclerotia of M. phaseolina caused by Bacillus sp. BS14; (A) Control; (B) hyphal lysis and cell shrinkage; (C) loss of vigour and mycelia fragmentation; (D) hyphal fragmentation, shrinkage, loss of vigour, and loss of sclerotia integrity 


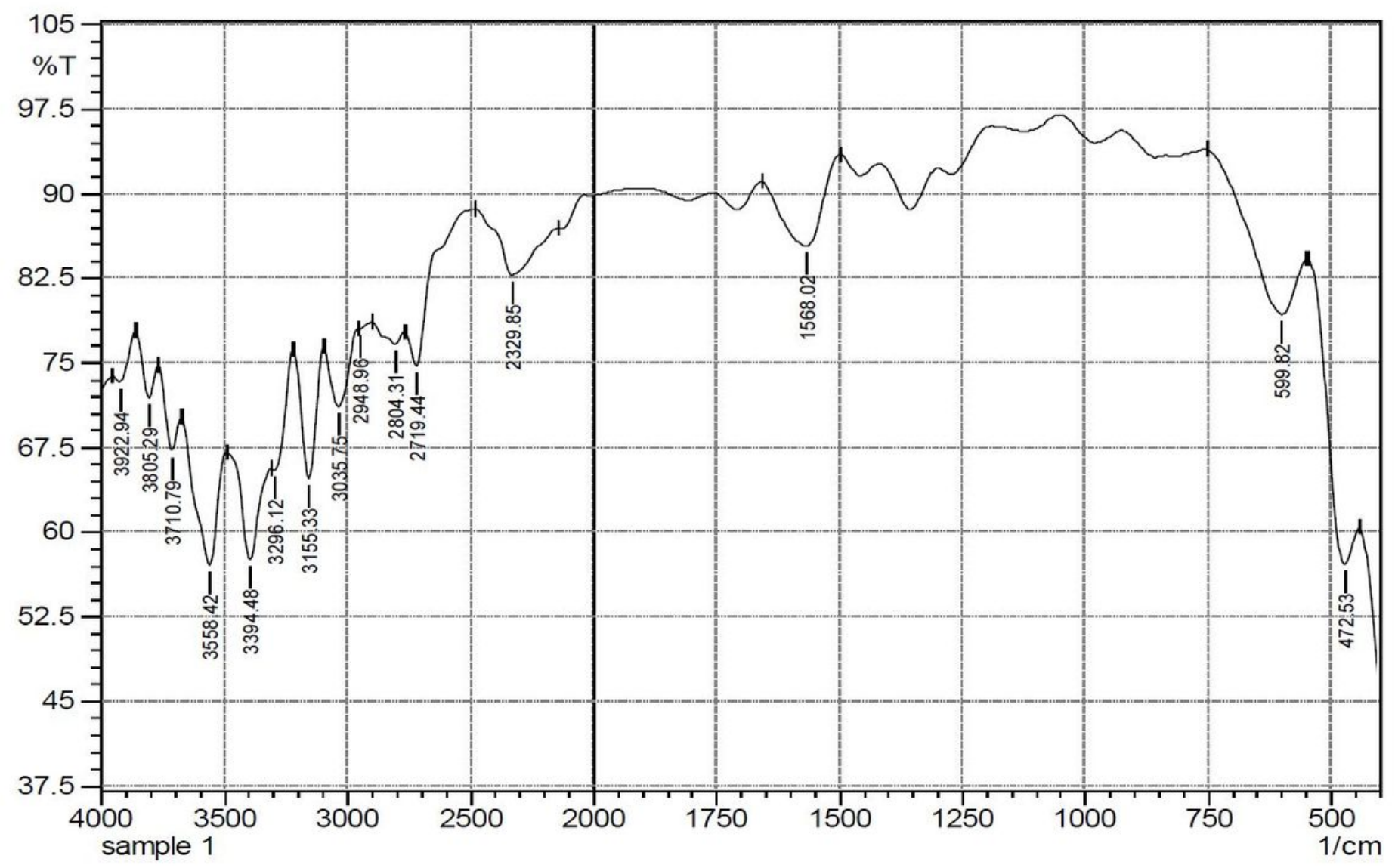

Figure 3

FTIR spectroscopy analysis of biosurfactant produced by Bacillus sp. BS14 


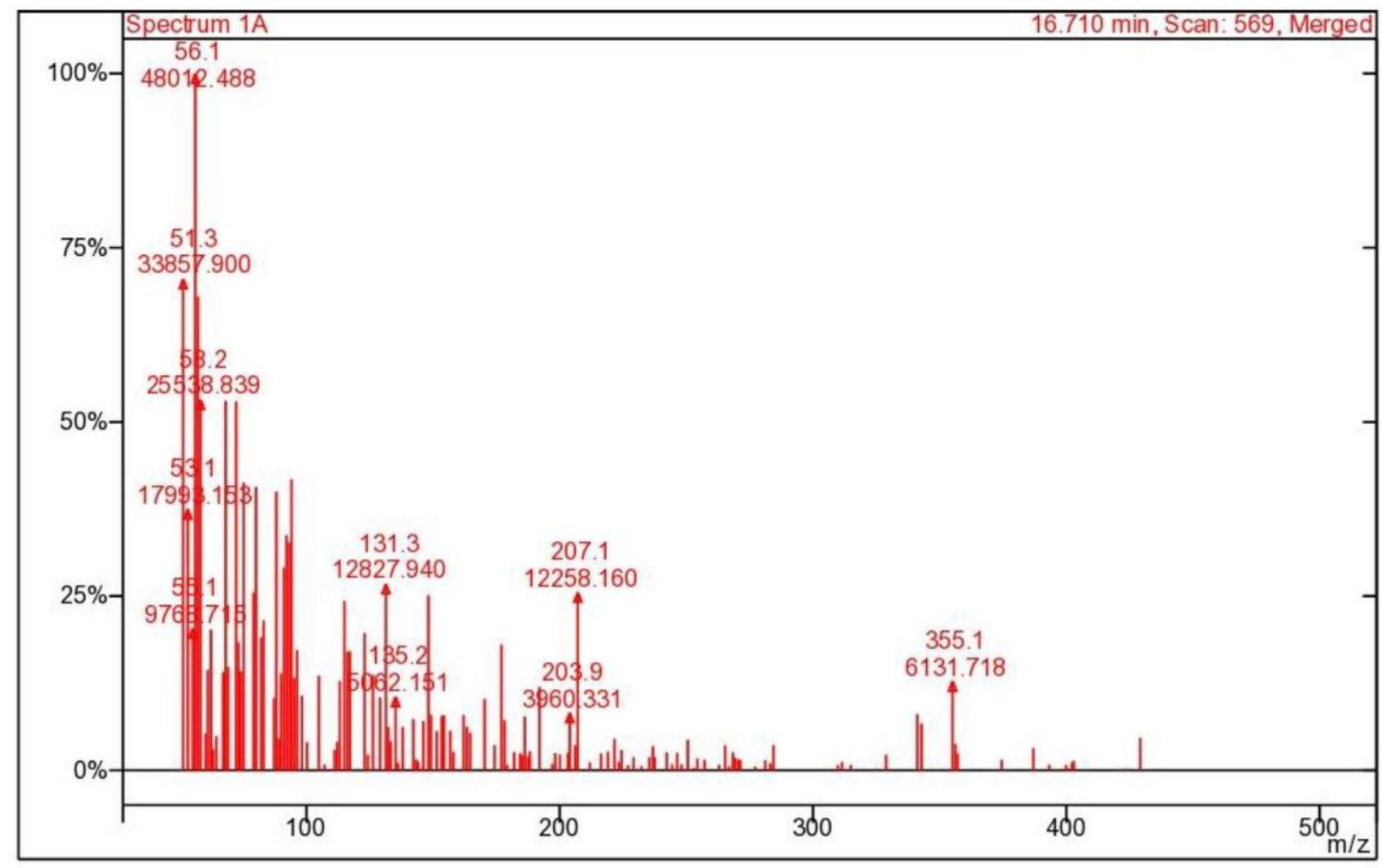

Figure 4

GC-MS spectra of purified biosurfactant produced by Bacillus sp. BS14. 